\title{
EFEKTYWNOŚĆ ŚRODKÓW USPOKOJENIA RUCHU W MIASTACH W KONTEKŚCIE ZANIECZYSZCZENIA ŚRODOWISKA
}

\begin{abstract}
Szacuje się, że krajach Unii Europejskiej (UE) około 20\% emisji dwutlenku węgla $\left(\mathrm{CO}_{2}\right)$ wydzielanego do powietrza pochodzi z różnorodnych form transportu. Ilość emisji $\mathrm{CO}_{2}$ pochodząca $\mathrm{z}$ transportu drogowego wzrosła w ciągu ostatnich 25 lat o około 23\%. Transport drogowy jest jedyną gałęzią przemysłu w Unii Europejskiej, w której emisja gazów cieplarnianych ulega ciągłemu wzrostowi. W obszarach zurbanizowanych lekkie samochody ciężarowe, samochody dostawcze i osobowe są głównym źródłem zanieczyszczeń. Na poziom zanieczyszczenia dodatkowo wpływają liczne zatory tworzące się w miastach w godzinach szczytów komunikacyjnych oraz spowodowany tym brak płynności jazdy. Efektywne zarządzanie ruchem drogowym umożliwia poprawę warunków ruchowych w miastach. Wzrost efektywności postępuje wraz ze wzrostem kontrolowanego obszaru, jednak w krajach rozwijających się, do jakich zalicza się Polskę, z uwagi na koszty wdrażania zarządzanie ruchem sprowadza się do pojedynczych punktów lub wybranych ciągów ulicznych. W takich miejscach instaluje się przede wszystkim środki spowalniające ruch pomijając ich wpływ na sposób jazdy kierowców. Celem referatu jest analiza wpływu obecności wybranych środków uspokojenia ruchu na dynamikę jazdy kierowców oraz wielkość emisji spalin samochodowych w obszarze zabudowanym. W referacie przedstawiono wyniki badań prędkości chwilowych pojazdów w otoczeniu wybranych środków uspokojenia ruchu w Białymstoku. Badania skoncentrowano na zachowaniach kierowców i zmianach dynamicznych zarejestrowanych prędkości. Dynamikę zmian określono w oparciu o indywidualne profile prędkości. Uzyskane wartości przyspieszeń i opóźnień umożliwiły oszacowanie wpływu określonych środków uspokojenia ruchu na zanieczyszczenie środowiska.
\end{abstract}

Słowa kluczowe: emisja spali, uspokojenie ruchu, prędkość, dynamika jazdy

\section{Wprowadzenie}

Zanieczyszczenia spalinami samochodowymi stają się co raz bardziej dokuczliwym problemem w wielu miastach w Polsce i na świecie. Transport jest źródłem około 25\% całkowitej ilości emisji gazów cieplarnianych (GHG) w Eu-

${ }^{1}$ Robert Ziółkowski, Politechnika Białostocka, Zakład Inżynierii Drogowej, ul. Wiejska 45E, 15-351 Białystok; tel. 797995989; robert.ziolkowski@ pb.edu.pl 
ropie i obecnie jest na drugim miejscu na liście największych emiterów gazów cieplarnianych. Transport drogowy odpowiada za około $25 \%$ całkowitej ilości dwutlenku węgla będącego podstawowym składnikiem gazów cieplarnianych. O ile emisję spalin wśród innych dziedzin na przestrzeni ostatnich lat udało się skutecznie ograniczyć i ilości wytwarzanych szkodliwych substancji systematycznie spadają, o tyle w przypadku transportu zanieczyszczenie środowiska spalinami nie tylko nie maleje, ale ulega ciągłemu wzrostowi. Jednym z powodów jest produkowanie coraz to większych i energochłonnych samochodów [1]. Ponad 67\% emisji zanieczyszczeń gazami cieplarnianymi jest efektem rosnącej liczby samochodów, mobilności społeczeństwa i odbywanych podróży. Zanieczyszczenia spalinami samochodowymi powstają w następstwie procesu spalania oraz parowania lotnych składników paliw płynnych, których podstawowymi składowymi są: tlenki azotu $\left(\mathrm{NO}_{\mathrm{x}}\right)$, azot $\left(\mathrm{N}_{2}\right)$, dwutlenek węgla $\left(\mathrm{CO}_{2}\right)$, tlenek węgla $(\mathrm{CO})$ oraz związki węglowodorowe $(\mathrm{CH})$. Przewiduje się, że w roku 2050, uwzględniając ogólnoświatowe trendy rozwoju motoryzacji, emisja $\mathrm{CO}_{2}$ pochodząca z transportu osiągnie poziom 30-50\% ogólnej emisji [2].

Obecnie poszukując rozwiązań narastającego problemu podkreśla się, oprócz fizycznego ograniczania liczby samochodów i wdrażania nowoczesnych technologii redukujących emisję spali, coraz większą rolę techniki jazdy jako czynnika istotnie wpływającego na poziom emisji spali.

\section{Zarządzanie prędkością i uspokojenie ruchu}

Zarządzanie prędkością to oddziaływanie na prędkość pojazdów poprzez stosowanie środków prawnych, planistycznych, technicznych oraz zaawansowanych technologii teleinformatycznych zmierzających do wymuszenia na kierowcach dostosowania się do wprowadzanych regulacji.

Do podstawowych form zarządzania prędkością $\mathrm{w}$ miastach zalicza się środki prawno-administracyjne oraz szeroką gamę rozwiązań inżynierskich w postaci środków fizycznych stanowiących różnorodne formy przeszkód umieszczanych w pasie drogowym.

Uspokojenie ruchu jest definiowane jako zespół działań o charakterze organizacyjnym, budowlanym i prawnym, których celem jest zmniejszenie negatywnego wpływu ruchu samochodowego na środowisko oraz modyfikacja zachowań kierowców poprzez zastosowanie odpowiednich środków technicznych. Skuteczność uspokojenia ruchu wiąże się z kompleksowym i skoordynowanym wdrażaniem fizycznych środków inżynierii drogowej i organizacji ruchu. W Polsce do uspokojenia ruchu stosuje się głównie indywidualne środki, które nie tworząc skoordynowanej całości wykazują mniejszą od oczekiwanej skuteczność. Z grupy środków fizycznych najczęściej stosuje się rozwiązania w postaci progów zwalniających i podrzutowych występujących w różnych odmianach. Z gamy dostępnych środków wybór konkretnego wiąże się z zakładanym efektem jaki ma być osiągnięty oraz z miejscem w jakim ma być zastosowane określone rozwiązanie. 


\section{Emisja spalin}

Typowa charakterystyka jazdy samochodu składa się z jazdy z określoną prędkością, hamowania, przyspieszania oraz jazdy na biegu jałowym. Proporcje występujące pomiędzy poszczególnymi stanami ruchu, zależą od charakteru i sposobu jazdy kierowcy (jazda agresywna vs. jazda umiarkowana), charakterystyki drogi (autostrady, drogi lokalne i dojazdowe) oraz warunków ruchu, które istotnie wpływają na prędkość jazdy oraz, co istotniejsze z punktu widzenia wydzielania emisji spalin samochodowych, płynność potoków ruchu. Płynność jazdy w warunkach miejskich ulega największym wahaniom w okolicach skrzyżowań drogowych z sygnalizacją świetlną oraz w miejscach występowania fizycznych środków uspokojenia ruchu, które wymuszają na kierowcach znaczne redukcje prędkości i zatrzymania.

Jak wskazują dotychczasowe badania największy wpływ na poziom emisji spalin podczas jazdy samochodu ma określony sposób jazdy [4]. Wykazano, że zużycie paliwa jak i emisja zanieczyszczeń są kilkukrotnie wyższe podczas częstych manewrów hamowania i przyspieszania niż podczas jazdy $\mathrm{z}$ ustaloną prędkością. Z kolei późniejsze badania [5] wskazały, że na poziom emisji spalin wpływ ma znacznie większa liczba czynników wśród których wymieniono średnią prędkość jazdy, średnie przyspieszenia oraz minimalną i maksymalną prędkość jazdy. Nie potwierdzono za to wpływu wielkości współczynnika opóźnienia na wielkość emisji spali. Podobnie badania analizujące wpływ prędkości i dynamiki jazdy [6] wykazały, że na poziom emisji spali wpływa dynamika przyspieszania, ale już dynamika opóźnienia takiego wpływu nie wykazała. Dodatkowo Wang [7] wskazał, że w modelach statystycznych odwzorowujących wielkość emisji większe znaczenie mają wskaźniki związane z dynamiką przyspieszeń zwłaszcza w niższych zakresach średnich prędkości.

Jednym ze sposobów mogących przyczynić się do poprawy tego niekorzystnego zjawiska jest wdrażanie efektywnych rozwiązań z zakresu zarządzania prędkością w kierunku uspokojenia ruchu.

\section{Metodyka badań i wyniki}

Pomiary prędkości prowadzono w otoczeniu środków uspokojenia ruchu zlokalizowanych w Białymstoku. Do pomiarów prędkości zastosowano metodę przejazdu testowego z wykorzystaniem rejestratora danych GPS, który umożliwia gromadzenie danych o pozycji pojazdu i jego prędkości w interwale 1s. Pomiary prowadzono $\mathrm{w}$ godzinach pozaszczytowych dążąc do zapewnienia warunków odpowiadających ruchowi swobodnemu. Jako pojazd testowy wykorzystano samochód osobowy. W oparciu o zgromadzone dane wygenerowano indywidualne profile prędkości poszczególnych przejazdów testowych (rys. 1), na podstawie których opracowano średnie profile prędkości i wyznaczono wartości opóźnień „d” i przyspieszeń „a”. 


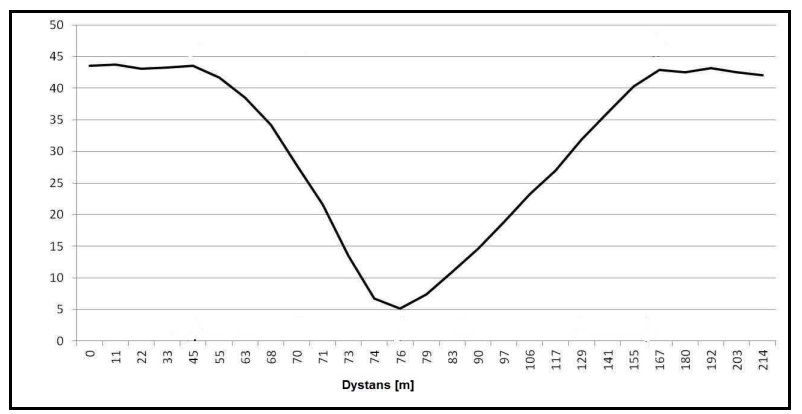

Rys. 1. Profil średniej prędkości w otoczeniu a) progu podrzutowego, b) małego ronda

Fig. 1. Average speed profile in vicinity of a) speed bump, b) small roundabout

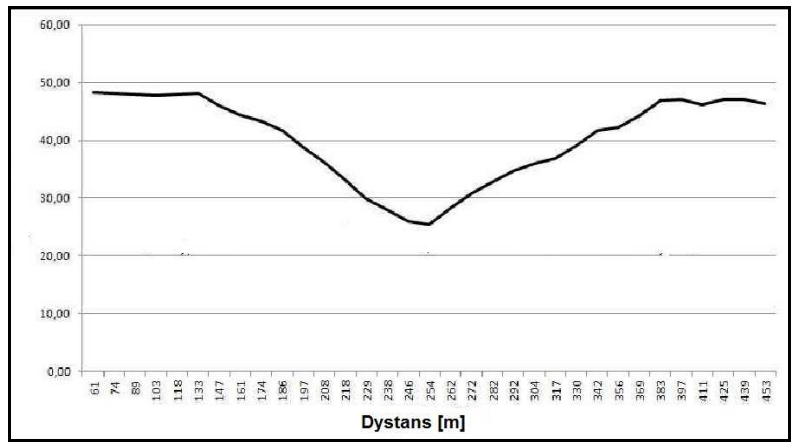

Rys. 2. Profil średniej prędkości w otoczeniu małego ronda

Fig. 2. Average speed profile in vicinity of a small roundabout

Spośród szerokiej gamy środków uspokojenia ruchu do szczegółowych badań wybrano te charakteryzujące się najwyższą skutecznością wymuszania na kierowcach redukcji prędkości. Badania prędkości prowadzono w otoczeniu progów podrzutowych, progów wyspowych, wyniesionych tarcz skrzyżowań drogowych i przejść dla pieszych. W badaniach uwzględniono także ronda małe i mini, które są coraz powszechniej stosowane jako środki uspokojenia ruch.

W oparciu o przeprowadzone pomiary opracowano indywidualne profile prędkości (Rys. 1,2) w otoczeniu każdego z wytypowanych środków uspokojenia ruchu. W oparciu o uśrednione profile określono średnie wartości opóźnień i przyspieszeń (Tabela 1) według wzoru:

$a, d=\Delta V / \Delta t$

gdzie: $d$-opóźnienie $\left[\mathrm{m} / \mathrm{s}^{2}\right]$,

$a$ - przyspieszenie $\left[\mathrm{m} / \mathrm{s}^{2}\right]$,

$\Delta V$ - przyrost/spadek prędkości [m/s],

$\Delta t-$ przyrost czasu [t]. 
Tabela 1. Zestawienie wyznaczonych wartości opóźnień i przyspieszeń

Table 1. Summary of calculated deceleration and acceleration values

\begin{tabular}{|l|c|c|c|c|}
\hline $\begin{array}{c}\text { Typ środka uspo- } \\
\text { kojenia ruchu }\end{array}$ & $\begin{array}{c}\text { Prędkość } \\
\text { dojazdowa } \\
{[\mathrm{km} / \mathrm{h}]}\end{array}$ & $\begin{array}{c}\text { Prędkość nad } \\
\text { środkiem uspoko- } \\
\text { jenia ruchu }[\mathrm{km} / \mathrm{h}]\end{array}$ & $\begin{array}{c}\text { Opóźnienie } \\
\text { "d” }\left[\mathrm{m} / \mathrm{s}^{2}\right]^{*}\end{array}$ & $\begin{array}{c}\text { Przyspieszenie } \\
\text { "a" }\left[\mathrm{m} / \mathrm{s}^{2}\right]^{*}\end{array}$ \\
\hline Mini rondo & 35 & 15,4 & $0,28-0,88$ & $0,51-1,01$ \\
\hline Małe rondo & 59 & 22,8 & $0,49-1,42$ & $0,51-1,42$ \\
\hline Próg podrzutowy & 43 & 4,3 & 1,09 & 0,9 \\
\hline Próg wyspowy & 43 & 27,1 & 0,69 & 0,7 \\
\hline $\begin{array}{l}\text { Wyniesiona tarcza } \\
\text { skrzyżowania }\end{array}$ & 50 & 4,7 & 1,37 & 0,80 \\
\hline $\begin{array}{l}\text { Wyniesione przej- } \\
\text { ście dla pieszych }\end{array}$ & 40 & 7,2 & 1,65 & 0,86 \\
\hline
\end{tabular}

*średnie wartości zależą od kierunku jazdy przez rondo

Przedstawione w Tabeli 1 wartości zarejestrowanych prędkości na odcinkach dojazdowych i nad środkami uspokojenia ruchu dowodzą ich dużej skuteczności oddziaływania na redukcję średniej prędkości pojazdów. Profile prędkości na Rys. 1 uwidaczniają, że występowanie środka uspokojenia również istotnie wpływa na technikę jazdy kierowców. Obecność progów podrzutowych, wyniesionego przejścia dla pieszych oraz wyniesionej tarczy skrzyżowania najistotniej wpływają na obniżenie prędkości, a średnia prędkość w miejscu ich występowania spada poniżej $10 \mathrm{~km} / \mathrm{h}$ i waha się od $4,3 \mathrm{~km} / \mathrm{h}$ (próg podrzutowy) do $7,2 \mathrm{~km} / \mathrm{h}$ (wyniesione przejście). W przypadku progów podrzutowych spadek prędkości jest również wyraźny lecz wartość redukcji prędkości nie przekracza $40 \%$ wartości prędkości notowanej na odcinku dojazdowym.

Charakter zmian prędkości w otoczeniu rond, jest bardzo podobny do zmian rejestrowanych w otoczeniu środków fizycznych. Najistotniejsza różnica sprowadza się do wartości prędkości na jezdni ronda. W przypadku mini rond średnia prędkość przejazdu jest o $11,7 \mathrm{~km} / \mathrm{h}$ niższa niż podczas przejeżdżania przez próg wyspowy.

Analizując dynamikę zachowań kierowców, najwyższe wartości opóźnienia zanotowano podczas zbliżania się do skrzyżowań $\mathrm{z}$ wyniesioną tarczą $\left(\mathrm{d}=1,37 \mathrm{~m} / \mathrm{s}^{2}\right)$ oraz przejść dla pieszych $\left(\mathrm{d}=1,65 \mathrm{~m} / \mathrm{s}^{2}\right)$. Zachowania takie można tłumaczyć tym, że kierowcy spodziewając się znacznej redukcji prędkości starają się maksymalnie opóźnić proces hamowania, co przekłada się na jego gwałtowność na krótkim odcinku przed przeszkodą. Najniższe wartości opóźnienia zanotowano przy zbliżaniu się do rond $\left(0,28 \mathrm{~m} / \mathrm{s}^{2}\right.$ i $\left.0,49 \mathrm{~m} / \mathrm{s}^{2}\right)$.

Analizując wartości przyspieszeń, istotniejsze w kontekście poziomu emisji spalin samochodowych, również zanotowano znaczne zróżnicowanie uzyskanych wyników. Najwyższe wartości zanotowano w otoczeniu rond małych i mini, odpowiednio a $=1,42 \mathrm{~m} / \mathrm{s}^{2}$ i a $=1,01 \mathrm{~m} / \mathrm{s}^{2}$. W otoczeniu pozostałych środków uspokojenia ruchu można zauważyć, że niższa prędkość przejazdu przez prze- 
szkodę wiąże się z wyższymi wartościami przyspieszeń notowanymi za przeszkodami.

Intensywne manewrowanie przyczynia się do wyższego zużycia paliwa i przez to wyższego zanieczyszczania środowiska naturalnego. Istniejące modele opisujące zużycia paliwa i wielkość emisji spali pojazdów poruszających się w warunkach generujących dużą zmienność prędkości jazdy [8] oraz modele uwzględniające wielkość emisji $\mathrm{CO}_{2}[9,10]$ w funkcji przyspieszenia wskazują na ich duży wzrost przy średnich prędkościach jazdy na poziomie $20-30 \mathrm{~km} / \mathrm{h}$ i przyspieszaniach przekraczających wartość $1,0 \mathrm{~m} / \mathrm{s}^{2}$, które to są charakterystyczne dla poruszania się w otoczeniu rond. Dodatkowo dynamiczne przyspieszanie przyczynia się do nawet $40 \%$ wzrostu emisji związków azotowych $\mathrm{NO}_{\mathrm{x}}$. Mając powyższe na uwadze, stwierdzić należy, że wdrażanie środków uspokojenia ruchu powinno się analizować nie tylko w zakresie ich skuteczności w zakresie redukcji prędkości lecz także w zakresie ich możliwego szkodliwego oddziaływania na środowisko i wielkości emisji szkodliwych substancji. Strategiczne zarządzanie prędkością nie powinno ograniczać się tylko do krótkich odcinków sieci ulicznej i do punktowych instalacji urządzeń spowalniających ruch w miejscach podwyższonego ryzyka drogowego, ale powinno obejmować swym oddziaływaniem większe obszary, tak aby wymusić na kierowcach poruszanie się z umiarkowaną, ale również jednolitą prędkością eliminując konieczność gwałtownych manewrów hamowania i przyspieszania. Dopiero takie rozwiązania będą zgodne z duchem strategii uspokojenia ruchu, która przewiduje wymuszenie na kierowcach nie tylko poruszanie się z prędkością bezpieczną, ale również w sposób przyjazny dla środowiska.

\section{Wnioski}

Uspokojenie ruchu jako element zarządzania prędkością jest niewątpliwie bardzo ważne nie tylko w aspekcie bezpieczeństwa ruchu drogowego i zachowań kierowców na drogach, lecz również w zakresie oddziaływania na środowisko. W referacie przeanalizowano efektywność wybranych środków uspokojenia ruchu $\mathrm{w}$ zakresie ich oddziaływania na prędkość jazdy i w odniesieniu do poziomu emisji spalin związanego z dynamiką zmian prędkości jazdy.

Wyniki badań wykazały, że spośród analizowanych środków uspokojenia ruchu najefektywniejsze w zakresie redukcji prędkości jazdy są urządzenia z grupy fizycznych środków uspokojenia tworzące fizyczne przeszkody na jezdni, zwłaszcza progi podrzutowe i wyniesione tarcze skrzyżowań. Ich efektywność jest znacznie wyższa w porównaniu do rond, ale wiąże się również z bardziej dynamicznymi manewrami hamowania wykonywanymi przez kierowców zbliżających się do nich.

Małe i mini ronda, które są chętnie stosowane jako środek uspokojenia ruchu faktycznie okazują się niekorzystnie i intensywnie oddziaływać na sposób jazdy kierowców powodując duże zróżnicowanie w prędkości jazdy. Zwłaszcza 
obecność małych rond stwarza warunki do dynamicznego hamowania i przyspieszania, których intensywność zależy od prędkości zbliżania się oraz obieranego kierunku jazdy przez rondo.

Zarządzanie ruchu może być efektywne nie tylko w zakresie oddziaływania na prędkość lecz również $\mathrm{w}$ aspekcie obniżania poziomu emisji spalin jednak w tym celu planowana strategia powinna być poprzedzona gruntowną analizą stanu istniejącego i zakładanego celu. Na poziomie lokalnym decyzje odpowiednich władz w kierunku kreowania zachowań kierowców przyjaznych nie tylko użytkownikom dróg lecz również środowisku mogą istotnie wpływać na poziom zużycia paliwa i emisji spalin. Jednak takie działania wymagają pogłębionych analiz uwzględniających sposób manewrowania kierowców w powiązaniu z określonymi środkami uspokojenia ruchu, w przeciwnym razie, uspokojenie ruchu może przyczyniać się do pogorszenia warunków środowiskowych.

"Badania zostaty zrealizowane $w$ ramach pracy $n r$ S/WBiIS/1/2015 i sfinansowane ze środków na naukę MNiSW"

\section{Literatura}

[1] Zachariadis T.J., editor (2012), Cars and carbon. Automobiles and European climate policy in a global context. Springer Business Media B.V.

[2] Fuglestvedt, J,. Berntsen T., Myhre G., Rypdal K., Skeie R.B. (2008), “Climate forcing from the transports sectors". PNAS 105 (2): 454-458.

[3] 2 European Environment Agency (2004) Analysis of Greenhouse Gas Emissions Trends and Projections in Europe, Eur Environ Agency, Copenhagen.

[4] Frey, H.; Rouphail, M.; Unal, A.; Colyar, J. 2001. Measurement of onroad tailpipe $\mathrm{CO}$, NO and Hydrocarbon emissions using portable instrument. Presented at the Annual Meeting of Air and Waste Management Association. 1-12. (2001).

[5] Unal, A.; Frey, H.; Rouphil, N. 2004. Quantification of highway emission vehicle emission hot spots based on on-board measurements, Journal of the Air and Waste Management Association, 54(2): 130-140.

[6] Bokare P.S., Maurya A.K. (2013) Study of speed, acceleration and deceleration of small petrol car on its tail pipe emission, International Journal of Traffic and Transport Engineering, 2013, 3 (4), 465-478.

[7] Wang, M.; Daamen, W.; Hoogendoorn, S.; Arem, B. 2011. Estimating Acceleration, Fuel Consumption, and Emissions from Macroscopic Traffic Flow Data, Transportation Research Record: Journal of the Transportation Research Board. DOI: http://dx.doi.org/10.3141/2260- 14, 2260(2011): 123-132.

[8] Pelkmans L, Debal P, Hood T, Hauser G, Delgado MR. Development of a simulation tool to calculate fuel consumption and emissions of vehicles operating in dynamic conditions. SAE 2004 spring fuels and lubricants, 2004-01(1873).

[9] Cornelis E, Broekx S, Cosemans G, Pelkmans L, Lenaers G. Impact of traffic flow description and vehicle emission factor selection on the uncertainty of heavy-duty vehicle emission calculation. VKMTHD Mitteilungen, vol. 85 (1). ; 2005. p. 13-21.

[10] Panis L.I., Broex S., Liu R. (2006) Modelling instantaneous traffic emission and the influence of traffic speed limits, Science of the Total Environment 371 (2006), 270-285. 


\section{EFFECTIVENESS OF TRAFFIC CALMING MEASURES IN URBAN AREAS IN SCOPE OF IMPACT ON THE ENVIRONMENT}

\section{S u m m a r y}

Times Road transport contributes about one-fifth of the EU's total emissions of carbon dioxide $\left(\mathrm{CO}_{2}\right)$, the main greenhouse gas. $\mathrm{CO}_{2}$ emissions from road transport increased by nearly $23 \%$ between 1990 and 2010. Transport is the only major sector in the EU where greenhouse gas emissions are still rising. Light-duty vehicles - most commonly present on urban roads - are a major source of greenhouse gas emissions, producing around $15 \%$ of the EU's emissions of $\mathrm{CO}_{2}$. Road conditions preventing smooth and fluent driving further enhance emissions. Efficient speed management covering vast city areas is belied to improve travel conditions and lower emissions. In developing countries due to high cost implementation speed management focuses basically on a smaller scale and aims at how best to set and enforce speed limits where there are safety concerns. Speed management being a complex issue involves both engineering and behavioural factors. Implementation of engineering issues involving physical and non-physical measures generally ignores behavioural factors that emerge from impediments that drivers face on a roadway which in turn essentially contribute to driving maneuvers and level of emissions. The measurements of instantaneous speed in vicinity of speed management measures including chosen traffic calming measures and roundabouts were undertaken to develop the investigation. The paper presents the results of speed investigations conducted in urban areas under varied roadway geometry conditions in two Polish cities. The examination has focused on drivers' behaviour and the dynamics of speed changes expressed by deceleration and acceleration values which have been evaluated on the basis of individual speed profiles. Data related to emissions were considered based on the literature.

Keywords: vehicle emission, traffic calming, speed, dynamics of maneuvers, acceleration

DOI:10.7862/rb.2016.301

Przestano do redakcji: $30.06 .2016 r$.

Przyjęto do druku: 20.12.2016 r. 